\title{
Architecture Studio Learning: Strategy to Achieve Architects Competence
}

\author{
Ahmad Saifudin Mutaqi ${ }^{1, *}$ \\ ${ }^{1}$ Associate Professor in Department of Architecture, Universitas Islam Indonesia, Indonesia
}

\begin{abstract}
In most Schools of Architecture, Architecture Studio is at the core of the architectural learning process. In the process, students are trained to have the skills of architectonic spaces design based on the study of the site, its function, and its aesthetics. Students are also trained to have awareness and understanding about the impact of their design on the surrounding environment, both physically and socially. Also, students are trained to present their designs in various forms such as visual graphics, verbal narratives, and three dimensional model animations. Indonesian Association of School of Architecture (APTARI Asosiasi Perguruan Tinggi Arsitektur Indonesia) and Indonesian Institute of Architects (IAI - Ikatan Arsitek Indonesia) has formulated an education Standards, Curriculum, and Achievements of Architect Professional Program to be referred by Ministry of Research, Technology, and Higher Education (KEMENRISTEKDIKTI - Kementerian Riset, Teknologi, danPerguruanTinggi) as the guidance for the implementation of Architect Professional Program (PPA - Pendidikan Profesi Arsitek) in Indonesia. One of the eight recommendations is the PPA Content Standard which contains the learning for the achievement of IAI Architect Competencies through the recommended study materials. However, the recommended study materials did not indicate the activity of the Architecture Studio learning model (Final Report of APTARI Part II and IAI). Will architect's competence be achieved if the learning process withoutarchitectural studio learning model? The formulation of the curriculum that is developed independently by the IAI recommends the learning of Architectural Studio as Professional Studio. The size of the SKS is large enough to enable someone who follows the lesson to intensively gain experience in designing the building as a real architectural work. This Architecture Studio learning model is interpreted by PPAr organizer universities with various forms, among others: (1) apprenticeship of architects; (2) supervised studios; And (3) project simulation studio. From various models of Architecture learning model mentioned above, all aim to achieve 13 Architect Competence as formulated by IAI. Which model is effective in learning the Architectural Studio mentioned above? This exploratory study would like to compare the three forms of Architecture Studio learning model to see how much the achievement of the targeted competencies by measuring the success of Competency Test activities still use the standards implemented by LPJK by involving assessors from IAI. The results of the comparison will show the compatibility of the implementation of the Architecture Studio learningmodel what is considered effective. These findings will certainly benefit the development of future PPAr implementation, especially if the Architecture Studio model can be commensurate with the studios developed by the School of Architecture in various countries, at least in the region of 21 member countries ARCASIA.
\end{abstract}

Keywords: Studio Architecture, Apprenticeship, Supervision, Simulation. Blended Learning in Heritage Conservation Course: Cultural Mapping and Google My Maps Platform

\section{Introduction}

\section{What is the Architectural Design Studio?}

The architectural design studio as a learning environment, including its pedagogy, history, and interaction, focusing on what makes the architectural design studio unique. Dutton (1984) stated that "compared to typical classroom scenarios, studios are active sites where students are engaged intellectually and socially, shifting between analytic,synthetic, and evaluative models of thinking in different sets of activities (drawing, conversing, model-making)" (p. 16). Although scholars have long praised the design studio as being a unique environment, there have also been criticisms (Ledewitz, 1985). For instance, Ledewitz said, "The lack of clarity over the purpose of the design studio reflects its complexity as a teaching learning setting" (p. 2). Another case with Salama is different withLedewitz's opinion. Salama (2005) claimed that "the design process is intended to function based on intuition, logical

*Corresponding author: ahmadsaifudin@uii.ac.id 
treatment, and rigorous reasoning" (p. 1). Nevertheless, the intent may not align with reality because instructors tend to teach how they were taught when they were in school (Salama, 2005). So, contrary to the literature on problem-based learning (PBL) and constructivism, even though design studio educators focus on a project-based technique of teaching (Salama, 1998) and it is obvious that design students should be responding with PBL actions, students' actions end up being constrained by the instructor's teaching format (Salama, 2005).Other scholars have viewed the design studio as a reflexive learning environment (Agryis, 1981; Anthony, 1991; Austerlitz, Aravot\& Ben-Ze'ev, 2002; Schön, 1985).

This reflexive quality is what makes the design studio stand out in higher education as a different educational environment (Schön, 1985) and is why, in architectural education, Kolb's learning style inventory (Kolb, 1984) and the idea of experiential learning is most commonly used by scholars to study learning in the architectural design studio. An example of this type of research is a study based in China that found biased correlation between the academicsuccess of students with different learning styles. The investigators concluded that students who were convergers (are students who are more apt to be successful in conventional systems, such as tests, and are more geared toward the physical sciences) were less successful in the architectural design studios being studied than assimilators (students whose strength lies in their ability to create theoretical models) (Jia\&Kvan, 2004). Another study by Kvan and Yunyan (2005) expanded on the aforementioned study, attempting to relate the design process to the process of experiential learning. Demirbas and Demirkan (2003) also embarked on the same journey as Kvan and Yunyan (although Demibras and Demirkan's focus was the design process through Kolb's learning styles and not experiential learning). Additionally, in design education, cognitive styles, described by Messick (1984) as "characteristic selfconsistencies in information processing that develop in congenial ways around underlying personality trends" (p. 61), are studied in relation to student progression in learning in architecture (Roberts, 2006, 2007); student understanding of architectural concepts in architecture (Saalman, 1990); artifact production in architecture, planning, and engineering (Akin \& Akin, 1996; Purcell \&Gero, 1998); and design process and cognition (Chan, 1995; Lui, 1996). ${ }^{\text {i }}$

Furthermore, Lueth explains in his book (p. 60) on the history of architectural design studio learning.The origins of the design studio are attributed to two art movements: the École des Beaux-Arts (School of Fine Arts) and the Bauhaus. Before the establishment of the design studio environment, design was learned through an apprenticeship model or a pupilage model, and the design professions were organized in guilds (Fisher, 2000; Kostoff, 1977). This type of education ensured that the master had control over the student (Kostoff). To provide a more structured education, deeming artists more credible through the development of art exhibitions, different académies (academies) were created. The most renowned of these, the French Académie Royale de Peinture et de Sculpture (The French Academy of Painting and Sculpture) (Draper, 1977; Kostoff; Van Zanten, 1980), was established in 1648 (Lagasse, Goldman, Hobson, \& Norton, 2001). Around this time (the 17th century), organized group education was established. Regardless of this group sensibility, the dominance of the master as the sole provider of knowledge remained.

Students later rose up against the École system because of the emergence of the modern movement. This student uprising in conjunction with the rise of the modern movement in architecture became a catalyst for the abandonment of the Beaux-Arts system (Littmann, 2000). The architect Walter Gropius was a prominent German leader of the modern movement (an architecture movement in the 20th century) that started in 1925 (Fitch, 1960; Nerdinger, 1985), and within the modern movement, the Bauhaus, established by Henri Van de Velde, arose (Frampton, 1985). The modern era's educational principles were geared toward training students as craftsmen, combining art with the modern technology of the time (Nerdinger), and the modern era itself was characterized by the use of steel as a building material and the use of art and architecture to serve people's special needs (Frampton). The modern-era teaching methods ranged from lecture courses to workshops where students would learn how to build from the day they stepped into the workshop (Gropius, 1937, 1968), while the Bauhaus workshop pedagogy, established for hands-on, interactive, and integrative learning, reinforced the design studio model as a place for all student activities to occur (Nerdinger).

The history of design education illustrates some important characteristics of the current design studio mode from its inception; however, Austerlitz, Aravot, and Ben-Ze'ev(2002) outlined four characteristics that make the modern day design studio a different learning environment than it was in the past: (a) the reflective learning component; (b) the personalized design process, which implies creativity; (c) the instructor's influence on the product of the project; and (d) the fact that a student's actions, personality, and feelings are laid out in the open. In contrast to this list, the traditional classroom has characteristics such as (a) the student as a blank slate mentality, (b) a non-requirement of creativity, (c) the instructor not having a direct influence on the process students use to produce work, and (d) an attitude that students' personalities are unimportant, mainly due to large classroom sizes. Indeed, other characteristics suggested by Lueth (2003) also make the design studio a unique educational environment unlike other environments: (a) the influence that students have on each other; (b) the influence that students could have on the instructor (in terms of creating an environment that may or may not be conducive to teaching); (c) the influence of the physical environment; and (d) the influence that the products created during class time and outside of class time might have on the students' learning. The educational environment in the design studio, therefore, is defined as the components of the physical, pedagogical, and virtual (the classroom through 
the internet) space that have an effect on the education of the participants (students and instructors).

In his book, Leuth concludes that there are a number of important statements related to what effects arise and what impacts.Participants spent a great deal of time talking about themes that fell under the category of interdependent learning. In the descriptions of their learning experiences, interdependency can be likened to the idea of constructionism, where knowledge and meaning are individually created, yet at the same time, there is a dependency on the relationships in the learning environment. The dependency on relationships allowed for a sharing of individual constructions and the generation of other meanings due to these interactions. These meanings can end up becoming shared meanings.

In the above study can be understood what is meant by Architecture Design Studio. The teaching and learning process that occurs in it involves a teacher and a number of students. Teachers can function as facilitators and / or instructors who have the authority to assess the work of students who follow the lectures. The process of interaction occurs naturally, taking place between them: the interaction of teachers and students and the interaction of students and students. The studio participants can start freely, be able to learn about understanding a problem, learn about finding solutions to a problem they've got. While the teacher as a facilitator can help students show important sources to understand the problem or to get the solution.

\section{Architectural Design Studio Model}

Researchers observed the teaching and learning process of Architectural Design Studio which was held in Architecture Profession Education Study Program, Universitas Islam Indonesia. There are three studio learning models: (1) Studio Internship Architecture; (2) Architectural Studio Supervised and (3) Studio Architecture Simulation Design.

\section{Studio Internship Architecture}

The Studio Internship Architectureare involving senior architect and intern architect. An intern architect or architectural intern is a person who is working professionally in the field of architecture in preparation for registration or licensure as an architect. An intern need not have attained a professional degree in architecture to begin accruing experience hours, but said degree is a prerequisite for licensure.In the United States, Canada, and other countries, an intern architect is enrolled in a regulated program, such as the Intern Development Program (IDP) in the United States or the Intern Architect Program (IAP) in Canada, while working under the supervision of a licensed architect and preparing for professional registration exams. The use of the title "architect" (or any derivation thereof) is legally protected in the United States, Canada, and other countries. Most U.S. states and all Canadian provinces, however, allow the use of the terms "intern architect" or "architectural intern" for a person enrolled in an architectural internship program."The term intern refers to any individual in the process of satisfying a registration board's experience requirements. This includes anyone not registered to practice architecture in a U.S. or Canadian jurisdiction, graduates from NAABaccredited programs, architecture students who acquire acceptable experience prior to graduation, and other qualified individuals identified by a registration board." National Council of Architectural Registration Boards (p. 2).

At the Chabot School of Architecture, the learning of an Architecture Internship is arranged with specific requirements.Architecture Internship in Architecture department setting approved by Architecture faculty as related to student's architecture major or classes at Chabot. Cooperative effort between student and architecture firm supervisor to accomplish agreed upon work objectives and broaden experiences. Student provides verification of service experience hours during the term. Students will get an architecture firm approved by architecture faculty and make arrangements for hours and duties directly with architecture firm supervisor. Students will meet with architecture instructor one hour per week on campus for input and hands-on experience discussion focused on architecture firm structures, project procedures, design developments and construction documents.Before entering the course, the student should be able to ${ }^{\text {ii }}$ :

1. Discuss construction using masonry, steel, concrete, and wood frame construction;

2. Demonstrate ability to use the Uniform Building Code for non-residential projects;

3. Prepare complete working drawings for small masonry, steel, and wood frame buildings;

4. Identify and execute critical details for construction documents;

5. Discuss the roles working drawings and specifications have in construction contract administration;

6. Use computer-aided design \& drafting, CD-ROM based information, and Internet resources for compiling construction documents.

7. Define in words and diagrams the central concept or part of a design;

8. Use both traditional and digital graphic and model building techniques to study design strategies;

9. Apply the role of human activity as determinant of and constraining element in design decisions;

10. Use functional objectives and constraints to affect the form and organization of architectural elements;

11. Manipulate architectural elements (floors, walls, roofs, openings) to define form and space that support the communication of intended meanings and concepts;

12. Adapt architectural design in response to a variety of site factors, including climatic, daylighting, and acoustic conditions;

13. Describe how cultural values and beliefs inform the perception and meaning of built environments;

14. Devise architectural designs in response to the cultural and anthropometric needs of occupants; 
15. Apply knowledge of structural potential and limitations as a design factor.

16. CAD organization and system components

17. Open, retrieve, and save drawing files in CAD;

18. Draw lines and geometric shapes using various coordinate entry systems in CAD;

19. Select and modify drawing entities in CAD;

20. Control lines, layers, and colors using AIA (American Institute of Architects) standards;

21. Place text with appropriate fonts and sizes in drawings by using CAD;

22. Dimension drawings using architectural standards in CAD;

23. Use external reference systems and commands in CAD;

24. Plot hardcopies with appropriate scales in CAD.

Taking into account the practice of apprenticeship of architecture above it seems that learning activities should be done together with the bureau of architects who work to serve the needs of architectural services. The requirement to follow the learning is very strict and skill issues should not be an obstacle for those who are dutiful to do architectural apprenticeship.

\section{Architectural Studio Supervised}

The supervised Architecture Studio is a studio workplace by apprentice architects managed and supervised by lecturers on campuses. The apprentice architects study and work with senior architects to resolve the real issues facing the demands of their contextual needs and contextual sites. the communication process undertaken by senior architects and interns is monitored directly by the supervisors.Learning and work activities undertaken in architectural design studios located on campuses are influenced by the order of design process undertaken by senior architects in managing their clients. The characteristics of each building planning project have different situations but the process stages can still be grouped into categories: programmatic design (feasibility studies and design concepts); schematic design (and preliminary design); design development and construction document (detailed engineering design)

Table 1. Subjects and Activity Topics ${ }^{\mathrm{iii}}$

\begin{tabular}{|c|c|}
\hline Subjects & Activity Topics \\
\hline $\begin{array}{l}\text { Programmatic Design } \\
\text { 1. The method of tracking and } \\
\text { preparing the design program for } \\
\text { a design project. }\end{array}$ & $\begin{array}{l}\text { - } \quad \text { Conferences with the user +owner } \\
\text { - } \quad \text { Surveyandcollecting structuring data } \\
\text { Analysis of Project Requirement (program analysis and concepts, } \\
\text { site analysis, space analysis, } \\
\text { - Building code information } \\
\text { - } \quad \text { Asiagram studies of Space Requirement } \\
\end{array}$ \\
\hline $\begin{array}{l}\text { Schematic Design } \\
\text { 2. The relationship between people } \\
\text { and buildings and between } \\
\text { buildings and the environment. } \\
\text { 3. Architectural design that meets } \\
\text { the aesthetic and technical } \\
\text { requirements. }\end{array}$ & $\begin{array}{l}\text { - Schematic design studies and recommended Solution } \\
\text { - Schematic design plan } \\
\text { - } \quad \text { Sketches and study model } \\
\text { - } \quad \text { Engineering system concept } \\
\text { - Preliminary cost estimate } \\
\text { - Presentation of SD documents to Owner }\end{array}$ \\
\hline $\begin{array}{l}\text { Design Development } \\
\text { 4. Knowledge of the construction } \\
\text { industry, organization, rules and } \\
\text { procedures for the } \\
\text { implementation of design } \\
\text { concepts into integrated and } \\
\text { comprehensive building planning. }\end{array}$ & 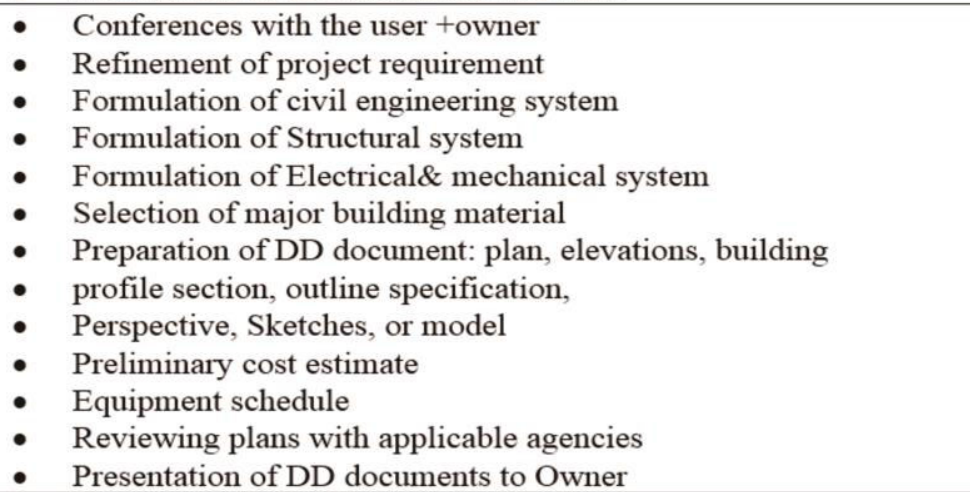 \\
\hline $\begin{array}{l}\text { Construction Document } \\
\text { 5. Skills required to meet } \\
\text { requirements within the range of } \\
\text { development and building } \\
\text { regulatory constraints. }\end{array}$ & $\begin{array}{l}\text { - } \quad \text { Conferences with the user +owner } \\
\text { - } \quad \text { Development of major detail condition } \\
\text { - } \quad \text { Diagram study of major mechanical and electrical system } \\
\text { - } \quad \text { Architectural working drawings, specifications } \\
\text { - } \quad \text { Civil working drawings, specifications } \\
\text { - } \quad \text { Structural working drawings, specifications } \\
\text { - } \quad \text { Electrical working drawing, specifications } \\
\text { - } \quad \text { Built-in equipment working drawings, specifications } \\
\text { - } \quad \text { Submission of construction documents to applicableagencies } \\
\text { - } \quad \text { Presentation of CD documents to Owner }\end{array}$ \\
\hline
\end{tabular}


If observed the study of architecture studios supervised above can be seen the existence of more controlled process guarantees by higher education institutions as education providers. The working atmosphere in an apprentice studio would not be as ideal apprentice studio would not be as ideal as studios owned by architectural consulting firms. But the control of the learning process step by step more can be guaranteed to be achieved. The process of education between lecturers and students and communication between senior architects and apprentice's architects can be more secure.

\section{Architectural Studio Simulation Project}

Architect work ${ }^{\text {iii }}$ : designing, not drawing. Images are simply communications mediums between architects and clients, contractors, or others involved in design and construction. To be an architect, students who are studying at the School of Architecture,Institut Teknologi Bandung (ITB), followed a series of designing training activities on Architecture Design Studio course, from semester 3 to semester 8. Designing exercises, starting from small buildings with simple problems. The semester is getting up, the building is getting bigger, the problems are solved in the more complex design, and the drafting exercise is not just designing the building but also the tread / environment around the building. In the studio, students practice designing while drawing, making a model or making 3D simulations. Explanation of activities undertaken by the School of Architecture ITB describes the working atmosphere in the project simulation studio.

Characteristics of architectural studios that use project simulations include:

1. The working order of the studio is set within the term of the reference of the project.

2. The technical requirements of the building are set according to the assumption of difficulty level that will be charged to the students.

3. Supervisor is positioned as the project owner.

4. Building codes are sometimes manipulated to get a quasi-ideal state.

Learning activities through the Project Simulation Studio have no real risk, but architectural problem solving can be done ideally, especially overriding the budget factor and building regulations formally.

\section{Architect Competency}

A competency is the capability to apply or use a set of related knowledge, skills, andabilities required to successfully perform "critical work functions" or tasks in a definedwork setting. Competencies often serve as the basis for skill standards that specify thelevel of knowledge, skills, and abilities required for success in the workplace as well aspotential measurement criteria for assessing competency attainment.Competencies define the applied skills and knowledge that enable people tosuccessfully perform their work while learning objectives are specific to a course ofinstruction. Competencies are relevant to an individual's job responsibilities, roles andcapabilities. They are a way to verify that a learner has in fact learned what wasintended in the learning objectives

Architect Competence marks an architect having certain skills in the field of architecture achieved through long learning process at higher education and professional education. Higher Education and Professional Education are held jointly between the University and the Association of Architects Professions within 5 (five) years. Equality recognition of the achievement of competence and trust in the implementation of education is done through accreditation process by independent accreditation institution of architectural field (LAM Architecture).

\section{Union Internationale Architect (UIA)}

Members of the architectural profession are dedicated to standards of professionalism, integrity, and competence, and thereby bring to society unique skills and aptitudes essential to the sustainable development of the built environment and the welfare of their societies and cultures. Principles of professionalism are established in legislation, as well as in codes of ethics and regulations defining professional conduct:

1. Expertise: Architects possess a systematic body of knowledge, skills, and theory developed through education, graduate and post-graduate training, and experience. The process of architectural education, training, and examination is structured to assure the public that when an architect is engaged to perform professional services, that architect has met acceptable standards enabling proper performance of those services. Furthermore, members of most professional societies of architects and indeed, the UIA, are charged to maintain and advance their knowledge of the art and science of architecture, to respect the body of architectural accomplishment, and to contribute to its growth.

2. Autonomy: Architects provide objective expert advice to the client and/or the users. Architects are charged to uphold the ideal that learned and uncompromised professional judgment should take precedence over any other motive in the pursuit of the art and science of architecture. Architects are also charged to embrace the spirit and letter of the laws governing their professional affairs and to thoughtfully consider the social and environmental impact of their professional activities.

3. Commitment: Architects bring a high level of selfless dedication to the work done on behalf of their clients and society. Members of the profession are charged to serve their clients in a competent and professional manner and to exercise unprejudiced and unbiased judgment on their behalf.

4. Accountability: Architects are aware of their responsibility for the independent and, if necessary, critical advice provided to their clients and for the effects of their work on society and the environment. Architects undertake to perform professional services only when they, together with those whom they may 
engage as consultants, are qualified by education, training, and/or experience in the specific technical areas involved.

The fundamental requirements for registration/licensing/certification as an architect as defined above, are the knowledge, skills, and abilities listed below that must be mastered through recognized education and training, and demonstrable knowledge, capability, and experience in order to be considered professionally qualified to practice architecture ${ }^{\text {iv }}$.

1. An ability to create architectural designs that satisfy both aesthetic and technical requirements

2. An adequate knowledge of the history and theories of architecture and the related arts, technologies and human sciences

3. A knowledge of the fine arts as an influence on the quality of architectural design

4. An adequate knowledge of urban design, planning and the skills involved in the planning process

5. An understanding of the relationship between people and buildings, and between buildings and their environment, and of the need to relate buildings and the spaces between them to human needs and scale

6. An understanding of the profession of architecture and the role of the architect in society, in particular in preparing briefs that take account of social factors

7. An understanding of the methods of investigation and preparation of the brief for a design project

8. An understanding of the structural design, construction and engineering problems associated with building design

9. An adequate knowledge of physical problems and technologies and of the function of buildings so as to provide them with internal conditions of comfort and protection against the climate

10. The design skills necessary to meet building users' requirements within the constraints imposed by cost factors and building regulations.

11. An adequate knowledge of the industries, organizations, regulations and procedures involved in translating design concepts into buildings and integrating plans into overall Planning

12. Awareness of responsibilities toward human, social, cultural, urban, architectural, and environmental values, as well as architectural heritage

13. Adequate knowledge of the means of achieving ecologically sustainable design and environmental conservation and rehabilitation

14. Development of a creative competence in building techniques, founded on a comprehensive understanding of the disciplines and construction methods related to architecture

15. Adequate knowledge of project financing, project management, cost control and methods of project delivery

16. Training in research techniques as an inherent part of architectural learning, for both students and teachers

\section{Ikatan Arsitek Indonesia (IAI)}

Association of Indonesian Architects (IkatanArsitek Indonesia) as the only professional association of architects recognized by law has formulated 13 Architects' competence.Through the 13 points of competence that become the standard of certification qualification certification fulfillment of architects. Any architect applying for a new certificate is required to answer questions about these standards, as one of the evidence of deepening and involvement in any proposed project as a benchmark ${ }^{\mathrm{v}}$.

\section{Architectural Design}

The ability to produce architectural design that meets the aesthetic and technical requirements, and which aims to preserve the environment (Ability to create architectural designs that satisfy both aesthetic and technical requirements, and which aim to be environmentally sustainable)

2. Architectural Knowledge

Adequate knowledge of the history and theory of architecture including art, technology and human sciences (Adequate knowledge of the history and theories of architecture and related arts, technologies, and human sciences)

3. Art Knowledge

Knowledge of art and its influence on the quality of architectural design (Knowledge of the fine arts as an influence on the quality of architectural design)

4. Urban Planning and Design

Adequate knowledge of urban planning and design as well as the skills needed in the planning process (Adequate knowledge on urban design, planning, and the skills involved in the planning process)

5. Relationship between Human, Building and Environment

Understanding the relationship between people and buildings and between buildings and the environment also understands the importance of linking the spaces that are formed between people, buildings and the environment for human and human needs (Understanding of the relationship between people and buildings and the buildings and their environments, and the need to relate spaces between them to human needs and scale.)

6. Knowledge of Environmental Supporting Power Mastering adequate knowledge on how to produce the appropriate design of environmental carrying capacity (An adequate knowledge of the means of achieving environmentally sustainable design.)

\section{The Role of Architects in Society}

Understand the professional aspect in the field of Architecture and realize the role of architects in the community, especially in the preparation of terms of reference which take into account social factors (Understanding of the profession of architecture and the role of architects in society)

8. Preparation Work Design

Understand the search method and the preparation of a design program for a design project (Understanding of the methods of investigation and preparation of the brief for a design project.) 


\section{Understanding Inter-Disciplinary Problems}

Understanding structural, construction and engineering problems related to the design of buildings (Understanding of the structural design, construction, and engineering problems associated with building design.)

10. Physical Knowledge and Building Physics

Mastering adequate knowledge of physical and physical issues, technology and building functionality so that it can equip them with internal conditions that provide comfort and protection of the local climate (Adequate knowledge of physical problems and technologies as well as internal conditions of comfort and protection against climate.)

11. Implementation of Budget Limits and Building Regulations

Master the skills required to meet the requirements of building users in the construction and building construction cost constraints (Necessary design skills to meet building factors)

12. Knowledge of Construction Industry in Planning Mastering adequate knowledge of industry, organization, regulations and procedures relating to the process of translating the concept of design into building structures and the process of integrating the layout of the plans into a comprehensive planning (Adequate knowledge of the industries, organizations, regulations, and in translating design concepts into buildings and integrating plans into overall planning.)

\section{Project Management Knowledge}

Mastering adequate knowledge of project funding, project management and development cost control (Adequate knowledge of project financing, project management and cost control).

\section{How to Achieve Architect Competency?}

Architectural competence is achieved in three levels, namely: awareness; understanding and ability.

Table 2. Relationship of Studio Model with IAI Competency ${ }^{\text {iv }}$.
For each architecture studio model has a different level of ability than any required competence. Working atmosphere in an intensive internship studio has an effect on every individual working in it. Daily meetings with senior architects and working relationships with colleagues put pressure on them. Nevertheless, working in a studio on campus is no less intensive.

The supervising lecturer controls each day on the work instructions provided by senior architects each time periodical meetings. Working atmosphere is not obtained by students who study in the studio in campus, but the atmosphere of learning to work more intensively can be felt. Students realize that they are not solving the same problem, but each participant is busy with their respective affairs according to the project.The learning outcomes they get that illustrate the relationship of achievement of competence with the studio model in which they work are described in the table below ${ }^{\mathrm{vi}}$.

Awareness is the ability to directly know and perceive, to feel, or to be cognizant of events. More broadly, it is the state of being conscious of something.

Understanding is often, though not always, related to learning concepts, and sometimes also the theory or theories associated with those concepts. However, a person may have a good ability to predict the behavior of an object, animal or system - and therefore may, in some sense, understand it-without necessarily being familiar with the concepts or theories associated with that object, animal or system in their culture. They may, indeed, have developed their own distinct concepts and theories, which may be equivalent, better or worse than the recognized standard concepts and theories of their culture.

Ability include of Intelligence, logic, abstract thought, understanding, self-awareness, communication, learning, having emotional knowledge, retaining, planning, and problem solving. Ability also about knowledge, a familiarity with someone or something, which can include facts, information, descriptions, or skills. Skill, the learned ability to carry out a task with predetermined results.

\begin{tabular}{|c|c|c|c|}
\hline \multirow{2}{*}{ IAI Competency } & $\begin{array}{l}\text { Internship } \\
\text { Studio }\end{array}$ & $\begin{array}{l}\text { Supervised } \\
\text { Studio }\end{array}$ & $\begin{array}{c}\text { Simulation } \\
\text { Project }\end{array}$ \\
\hline & Off campus & In campus & In campus \\
\hline 1. Architecture Design & ability & ability & understanding \\
\hline 2. Architecture Knowledge & understanding & understanding & awareness \\
\hline 3. Art Knowledge & awareness & understanding & awareness \\
\hline 4. Urban Planning and Design & understanding & awareness & awareness \\
\hline $\begin{array}{l}\text { 5. Relationship between Human, Building and } \\
\text { Environment }\end{array}$ & understanding & understanding & awareness \\
\hline 6. Knowledge of Environmental Supporting Power & ability & ability & awareness \\
\hline 7. The Role of Architects in Society & ability & understanding & awareness \\
\hline 8. Preparation WorkDesign & ability & ability & understanding \\
\hline 9. Understanding Inter-disciplinary Problem & understanding & understanding & awareness \\
\hline 10. Building Physic and Physical Knowledge & ability & ability & understanding \\
\hline $\begin{array}{l}\text { 11. Implementation of Budget Limits and Building } \\
\text { Regulation }\end{array}$ & ability & ability & awareness \\
\hline 12. Knowledge of Construction Industry in Planning & understanding & understanding & awareness \\
\hline 13. Knowledge of Project Management & understanding & understanding & awareness \\
\hline
\end{tabular}




\section{Conclusion}

Learning process activities conducted in off-campus internship studios have a positive impact on students who develop themselves to work as architects. Internship activities to senior architects give many new experiences in dealing with real problems. The working atmosphere in the studio encourages students to work even though each one is doing different things. Students are 'forced' to work to resolve unscheduled issues caused by clients' requests or other reasons that make it necessary to work overtime. Officers off-campus apprentices may occasionally acquire undisciplined students, but the situation there forces students to follow the rules of the game. Achievement of learning competence still depends on the learning process that occurs between Supervisor, Senior Architect and Student. These three actors are very influential on the achievement of competence due to the delivery process, communication, problem complexity and sharing mechanisms in learning to work.

Studio internships and supervised studios are recommended for learning to achieve the architect's competence. Discipline of all actors (Students; Lectures; Architects) in the studio design and order as well as the commitment of teaching and learning process from them in the learning process become the key of success to achieve the competence of architect.

\section{References}

Lueth, Patience LamunuOpiyo, (2008), The architectural design studio as a learning environment: a qualitative exploration of architecture design student learning experiences in design studios from first- through fourth-year, Iowa State University.

ii Downloading at September 29, 2017: http://www.chabotcollege.edu/searchresults.asp?q=i nternship+architecture\&imageField.

iii Downloading at September 30, 2017: https://ar.itb.ac.id/2010/12/13/studio-perancanganarsitektur/

iv UIA Accord On Recommended International Standards Of Professionalism In Architectural Practice Ammended August 2014 At The Xxvi General Assembly (Durban, South Africa 2014)

v Downloading at September 30, 2017: http://www.iai.or.id/sertifikasi/13kompetensi

vi Result of evaluation of learning process at Archival Profession Program of Universitas Islam Indonesia for 3 years $(2013,2014,2015)$. 